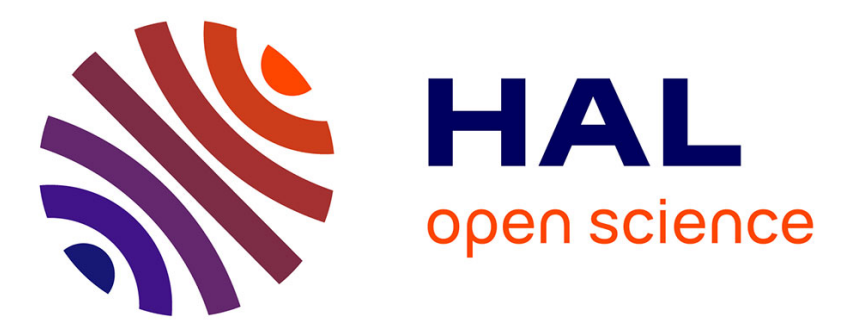

\title{
The substrate, a key factor or not, to explain the species diversity of diatom communities in mineral springs
}

Lory-Anne Baker, David G Biron, Fanny Millan, Olivier Voldoire, Vincent Breton, Elisabeth Allain, Carlos E Wetzel, Luc Ector, Aude Beauger

\section{To cite this version:}

Lory-Anne Baker, David G Biron, Fanny Millan, Olivier Voldoire, Vincent Breton, et al.. The substrate, a key factor or not, to explain the species diversity of diatom communities in mineral springs. Botany Letters, 2022, 169 (2), pp.155-165. 10.1080/23818107.2022.2028186 . hal-03562545

\section{HAL Id: hal-03562545 https://hal.science/hal-03562545}

Submitted on 9 Feb 2022

HAL is a multi-disciplinary open access archive for the deposit and dissemination of scientific research documents, whether they are published or not. The documents may come from teaching and research institutions in France or abroad, or from public or private research centers.
L'archive ouverte pluridisciplinaire HAL, est destinée au dépôt et à la diffusion de documents scientifiques de niveau recherche, publiés ou non, émanant des établissements d'enseignement et de recherche français ou étrangers, des laboratoires publics ou privés. 


\section{The substrate, a key factor or not, to explain the species diversity of diatom communities in mineral springs}

Lory-Anne Baker ${ }^{\mathrm{a}, \mathrm{b}^{*}}$, David G. Biron ${ }^{\mathrm{a}, \mathrm{b}}$, Fanny Millan ${ }^{\mathrm{c}}$, Olivier Voldoire ${ }^{\mathrm{c}, b}$, Vincent Breton $^{\mathrm{d}, b}$, Elisabeth Allain ${ }^{\mathrm{c}, \mathrm{b}}$, Carlos E. Wetzel ${ }^{\mathrm{e}}$, Luc Ector $^{\mathrm{e}}$ and Aude Beauger ${ }^{\mathrm{c}, b}$

${ }^{a}$ Université Clermont Auvergne, CNRS, LMGE, F-63000 Clermont-Ferrand, France; ${ }^{b}$ LTSER "Zone Atelier Territoires Uranifères", F-63000 Clermont-Ferrand, F-63178 Aubière Cedex, France, ' Université Clermont Auvergne, CNRS, GEOLAB, F-63000 Clermont-Ferrand,

France; ${ }^{d}$ Université Clermont Auvergne, CNRS/IN2P3, Laboratoire de Physique de Clermont (LPC), UMR6533, F-63178 Aubière cedex, France; ${ }^{e}$ Environmental Research and Innovation (ERIN) Department, Luxembourg Institute of Science and Technology (LIST), L4422 Belvaux, Luxembourg.

"Lory-Anne Baker, 1-anne.baker@etu.uca.fr, Université Clermont Auvergne, CNRS, UMR6023, LMGE, 63178 Aubière Cedex, France

\section{Notes on contributors}

All authors reviewed and approved the final manuscript.

Contribution: L.A.B., A.B and D.G.B. conceived and performed the study and experiments. L.A.B. designed and performed the statistical and data analyses with advises of her thesis directors A.B. and D.G.B., E.A. and V.B. help in field experiments. F.M. and L.A.B. performed the biological analysis of diatom communities. O.V. did the water analysis. C.E.W. helped in discussion of results, advised the taxonomic content. L.E. helped in provision of literature, discussion of results. L.A.B. wrote the main manuscript with A.B. and D.G.B. in consultation with F.M., O.V., V.B., E.A., C.E.W. and L.E.

\section{ORCID}

Lory-Anne Baker https://orcid.org/0000-0002-8346-8578

David G. Biron https://orcid.org/0000-0002-6531-4647

Fanny Millan https://orcid.org/0000-0001-8465-4527

Olivier Voldoire https://orcid.org/0000-0003-1306-3054 
Vincent Breton https://orcid.org/0000-0001-8197-7080

Elisabeth Allain https://orcid.org/0000-0002-6411-5873

Carlos E. Wetzel https://orcid.org/0000-0001-5330-0494

Luc Ector https://orcid.org/0000-0002-4573-9445

Aude Beauger https://orcid.org/0000-0002-0911-0500

\begin{abstract}
Diatoms colonised most aquatic ecosystems on earth from marine to freshwater ones, and also the springs containing a fairly large and poorly known diversity of diatoms. While investigations on the influence of substrates on diatom assemblages in rivers are relatively well documented, few studies have been done for mineral springs. The purpose of this study was to analyse if the type of substrate on which diatoms grow, influences diatom assemblage's ecological metrics (i.e. species richness, diversity and evenness) and diatom composition. During 18 months, two minerals springs of Auvergne (France), La Montagne and Mariol were sampled monthly, both epilithic and epipelic diatom communities. A total of 201 taxa were found. Data analysis showed that location (i.e. environmental variables of a site) explained significantly higher portions of variability of diatom composition than substrate. However, substrate have a role in the species abundances as much as the location.
\end{abstract}

Keywords: diversity of diatom community; substrate influence; community drivers; mineral springs

\title{
Introduction
}

Diatoms are a widely distributed group of unicellular algae that can colonised most of the habitats of aquatic ecosystems (ex.: lakes, rivers, estuaries, seas, oceans, springs) on earth (Mann and Drop 1996). For instance, benthic diatoms can grow in habitats of an aquatic ecosystem by attaching to substrates such as rock (epilithon), silt surface (epipelon), sand (epipsammon), plant (epiphyton) and wood (epidendron) (Round 1991). The assumption on a relationship between the substrate type and the species diversity or assemblage of benthic 
diatom communities in an aquatic ecosystem was assessed by many surveys in freshwater aquatic ecosystems like rivers and lakes. Some of these studies concluded that the substrate type should influence both species diversity and assemblage of benthic diatom communities in aquatic ecosystems (Cox 1988; Sabater et al. 1998; Soininen et al. 2004; Potapova and Charles 2005; Medlin and Juggins 2018).

Based on previous studies and on their results, Round (1991) suggested that substrate topology could drive the benthic diatom assemblage (community) colonising a given substrate. Therefore, attached diatoms are mostly found on hard surfaces (ex.: rock, wood) while motile ones are predominant on thin particles such as silt. Townsend and Gell (2005) suggested that benthic diatom assemblages were similar on hard substrates such as sand, wood and rock but not for the species abundance. On the other hand, they concluded that benthic diatom assemblages on vegetation substrates were in general dissimilar. Stevenson and Hashim (1989) analysed during two summers the diatom assemblages at two streams of Michigan State in the USA. They observed that the species abundances varied among microhabitats, and also that the differences of diatom species in studied communities were higher between rivers rather than habitats at a same sampling site. Moreover, many studies observed no significant difference between diatom communities from various substrates for the species composition (Sullivan 1982; Millie and Lowe 1983; O’Quinn and Sullivan 1983). For instance, Jüttner et al. (1996) showed that there were similarities of species diversity between habitats during their surveys on Nepalese streams.

If there are several studies on the influence of substrate types on the species diversity or assemblage of benthic diatom communities in rivers and lakes, few were done on springs. However, these aquatic-terrestrial ecosystems are widespread. The total number of springs on earth is estimated at more than $57 \times 10^{6}$ including approximately $10^{5}$ thermal springs (Cantonati et al. 2012a). Besides, springs are present in different contexts (Kresic 2010) and 
have diverse mineral compositions due to their origin and lithology. Some springs were used for medical purposes and also for drinking because of their special mineral composition. Thus, spring water catchment systems were made to collect underground water in many countries. Moreover, springs are also important because of their abundant and peculiar biodiversity (Cantonati et al. 2012a). Usually, springs are physically small biotopes where environmental variables are considered as stable. In fact, their stability depends on the spring type or configuration which can modified their endogenous chemical parameters.

Some authors focus on the influence of substrate on benthic diatom assemblages in springs (Cantonati 1998; Cantonati et al. 2009, 2012b; Wojtal and Sobczyk 2012; Lai et al. 2019b). For their survey at Sardinia (Italy), Lai et al. (2019b) concluded that diatom assemblages in these thermo-mineral springs formed separated clusters and are not similar for three substrates: rock, cobbles and sediments. In contrast, the results of Cantonati (1998) suggested that there were no differences between diatom assemblages growing on rock and plants. Similar conclusion was obtained by Wojtal and Sobczyk (2012) that also highlights that diatom distribution follows environmental variables like $\mathrm{pH}$, salinity, trophic level and physico-chemical parameters. According to these last observations, the study of 16 springs and 5 streams of Dolomiti Bellunesi National Park in Italia determined that environmental variables explained $40 \%$ of the variability of diatom species diversity and substrate $3 \%$. Therefore, these results suggest that macrohabitats have more impact on diatom assemblages than microhabitats (Cantonati and Spitale 2009). In order to bring new insights on the influence of substrate on benthic diatom assemblages in mineral springs, the epilithic and epipelic diatom communities of two springs located in Auvergne region were sampled monthly between July 2018 and June 2020 in order to test the spatio-temporal relationships between the substrate type and the species diversity. 


\section{Material and methods}

\section{Sampling sites}

Two mineral springs, so called La Montagne and Mariol, were used for this survey (Figure 1). Both are rich in bicarbonate and sodium, and belong to the springs of Châteldon, Vichy and the Saint-Yorre basins which take origin into the eastern border faults. The first one, La Montagne, is located in Châteldon (E 741086.699, N 6542796.817 in Lambert 93). At this spring, water is taken from the ground and discharged into a former building constructed during the bottling period (1859 - early 1900s). The second spring studied, Mariol, is located in the city of Mariol (E 739134.341, N 6546926.368 in Lambert 93) at 5 km from Châteldon and takes part of the South of Vichy basin. At this site, the water springing in a basin $50 \mathrm{~cm}$ above the ground. Both springs are located outside of the protected catchment area of the Vichy hydrotherapy industry and therefore accessible for sampling.

\section{Physical and chemical analyses of water}

Eighteen samples were taken between July 2018 and June 2020. Dissolved oxygen (\%), conductivity $\left(\mu \mathrm{S} . \mathrm{cm}^{-1}\right)$ and water temperature $\left({ }^{\circ} \mathrm{C}\right)$ were measured in situ using an Ysi ProODO oxygen probe and a multi-parameter WTW probe FC 340i. The carbonate concentration $\left(\mathrm{HCO}_{3}{ }^{-}\right)$was also measured using a Hach carbonate kit. Additionally, during each sampling, a water sample was collected for further laboratory chemical analysis using a high pressure ion chromatography technic. First, these samples were filtered using Whatmann GF/C filters. For cation and anion analysis, a Thermo Scientific Dionex ICS1100 and a Thermo Scientific Dionex Aquion system were respectively used to measure concentrations (mg. $\left.\mathrm{L}^{-1}\right)$ in lithium $\left(\mathrm{Li}^{+}\right)$, sodium $\left(\mathrm{Na}^{+}\right)$, ammonium $\left(\mathrm{NH}_{4}{ }^{+}\right)$, potassium $\left(\mathrm{K}^{+}\right)$, magnesium $\left(\mathrm{Mg}^{2+}\right)$, calcium $\left(\mathrm{Ca}^{2+}\right)$, fluoride $\left(\mathrm{F}^{-}\right)$, chloride $\left(\mathrm{Cl}^{-}\right)$, nitrite $\left(\mathrm{NO}_{2}^{-}\right)$, nitrate $\left(\mathrm{NO}_{3}^{-}\right)$, phosphate $\left(\mathrm{PO}_{4}{ }^{3-}\right)$ 


\section{Sampling of diatom communities}

Both epipelic (on mud) and epilithic (on pebble) samples were collected from the two springs during 18 months between July 2018 and June 2020. "Mud" is referred to fine sediment with low quantity of silt, and "pebble" is referred to basalt stone (classified particles size: $64-128$ $\mathrm{mm}$, Malavoi and Souchon 2002). The epipelic sample depends of the kind of substrate presents on each site. Thus diatoms were sampled from a mix of mud and litter at La Montagne spring and from a mix of organic matter and non-hardened calcium carbonate from the travertine at Mariol spring. For the first site, the sediments were recovered by scraping off the first millimetres of mud directly with the vial, and for the second one, by brushing the non-hardened deposits. Epilithic samples were collected on basalt pebbles previously recovered from Allier river that were sterilised and placed in spring water. Epilithic algal communities were sampled by brushing the attached algae from the upper surface of submerged pebble using Douglas (1958) method.

\section{Slide preparation and microscopy}

Small sub-samples of epipelic and epilithic raw material were prepared for light microscopy (LM) observation according to the method of Prygiel and Coste (2000). Samples were cleaned using hydrogen peroxide $\left(\mathrm{H}_{2} \mathrm{O}_{2}, 35 \%\right)$ and hydrochloric acid $(\mathrm{HCl}, 37 \%)$, and rinsed several times with distilled water. Cleaned material was diluted with distilled water to avoid excessive concentrations of diatom valves on the slides. Then, a drop of dried, clean material was mounted in Naphrax ${ }^{\circledR}$. LM observations and morphometric measurements were done using a Leica® DM2700M microscope with a 100x oil immersion objective using a differential interference contrast. For each slide, 400 valves were enumerated on random transects. Diatom identification was based on different taxonomical works (Krammer and Lange-Bertalot 1997a, 1997b, 2000a, 2000b, 2004; Krammer 2000, 2002, 2003; Lange- 
Bertalot 2001; Kulikovskiy et al. 2010; Hofmann et al. 2013; Wetzel et al. 2015; LangeBertalot et al. 2017). Once the counting was completed, the relative abundance of diatom species was calculated.

\section{Data analysis}

\section{Physical and chemical parameters}

Abiotic data do not follow a normal distribution; thus there were standardised using z-score normalisation ((x-mean)/standard deviation) for Principal component analysis (PCA) (Abdi and Williams 2010). This transformation allows also to compare variables that initially had different units. From the 18 months of sampling, a stepwise regression was done in order to retain the most significant environmental variables from the dataset using XLSTAT 20203.1 software. As an outcome, conductivity, $\mathrm{Cl}^{-}, \mathrm{NO}_{3}{ }^{-}, \mathrm{F}^{-}$and $\mathrm{HCO}_{3}{ }^{-}$were retained as the most relevant parameters. Because of their ecological importance in spring ecosystems and on diatoms communities (Patrick 1977): temperature, dissolved oxygen, $\mathrm{pH}$, anthropogenic indicators $\left(\mathrm{NO}_{2}^{-}, \mathrm{NO}_{3}{ }^{-}, \mathrm{PO}_{4}{ }^{3-}\right)$ and a geological indicator $\left(\mathrm{Na}^{+}\right)$were added to the environment variables selected through the stepwise regression. Then, a PCA was performed on these parameters to detect temporal and local differences among samplings. Statistical difference between Mariol and La Montagne samples was statistically tested with the non-parametric Krukal-Wallis test based on the Cartesian coordinates of the PCA samples points.

Related to our observations during the survey, it seems that La Montagne spring could be affected by high precipitation events due to its configuration. To take into consideration the evolution of water conductivity and daily precipitations (data from US1116 AGROCLIM, INRA, Centre de Recherches PACA) during the sampling period, boxplots and graphs were also done with XLSTAT 20203.1 version. The correlation between these variables was tested by calculating Pearson correlation coefficient. 


\section{Statistical analysis of diatom data}

Three diversity indices: Species richness (R), Shannon-Wiener index (H) and Evenness (J), were calculated for each spring. For each index, the comparison between substrate types was done by using the Wilcoxon test to verify the null hypothesis (no effect) of substrate. Further, to compare the composition of the diatom communities between substrates and considering the large sample size, the Jaccard dissimilarity index (Jaccard 1901) was the most appropriate index. This one only takes account of the species shared between the two assemblages and the number of unique species of each assemblage. So, when the matrix of dissimilarities was generated with the function vegedist of the R package "vegan" (version 2.5-7), the arguments of the function were configured to convert the species relative abundances matrix into a binary matrix ( 0 : absence, 1 : presence) before running the distances matrix. A second matrix with the abundances-based jaccard dissimilarity index "ab.jaccard” (or chao jaccard) described in Chao et al. (2006) was also generated. The ab.jaccard distances is not present in vegan package so the dist.ldc function of the package "adespatial" version 0.3-14 (Dray et al, 2012) was used to generate a dissimilarity matrix with this index. These matrices were used for a non-metric Multidimensional Scaling ordination analysis (nMDS) performed to explore the similarity of diatom assemblages between the two substrates (pebble or mud) located in a same spring (XLSTAT 20203.1 version). Kruskal-Wallis stress was calculated to assess the nMDS adjustment quality (stress>0.20: bad adjustment, $0.10<$ stress $<0.20$ : adequate, $0.05<$ stress $<0.025$ : good, stress $<0.025$ : excellent and stress $=0$ : perfect $)$. To complete the nMDS analysis and validate the significance of the differences between samples, a one-way analysis of similarities (ANOSIM) was used (Clarke 1993). The ANOSIM were also done with Jaccard distances matrix and ab.jaccard distances. The percentage of contribution of three factors (location, season, substrate) to the variability of diatom species diversity in springs was determined by using a Non-parametric MANOVA analysis (i.e. ADONIS 
(Permutational MANOVA)) based on Jaccard or ab.jaccard dissimilarity index using the function Adonis of the vegan R package.

\section{Results}

\section{Physical and chemical analyses of La Montagne and Mariol springs}

The physical and chemical measures done at Mariol and La Montagne springs during the 18 months of sampling are reported in Tables 1, 2 and 3. The PCA (Figure 2) performed on environmental variables explained $53.96 \%$ of the variance (axis 1: $32.26 \%$ and axis 2: 21.69 $\%)$. The axis 2 clearly separates La Montagne and Mariol samples in two groups (KruskalWallis test: $\mathrm{p}<0.0001)$. Mariol samples were associated with high concentrations of fluoride and high temperatures (upper part of the first factorial plan). Compared to Mariol, La Montagne samples formed a disperse cluster in the lower part of the factorial plan. Samples collected in April 2019, October to December 2019, January and February 2020 are associated with high concentrations of $\mathrm{Cl}^{-}, \mathrm{SO}_{4}{ }^{-}, \mathrm{NO}_{3}{ }^{-}$and $\mathrm{PO}_{4}{ }^{3-}$. Most of the samples of $\mathrm{La}$ Montagne spring are related to high concentrations of $\mathrm{HCO}_{3}{ }^{-}$and high conductivity. Indeed, La Montagne waters have a conductivity that varies significantly contrary to Mariol (Table 1). While Mariol spring water emerges in a basin $50 \mathrm{~cm}$ above the ground, La Montagne spring water flows from a cavity on an abandoned building floor and can merge with streaming waters. As a consequence, we hypothesised that the variations in conductivity of this spring were linked to precipitations leading to spring waters more affected by dilutions.

Figure 3 shows respectively the evolution of water conductivity and daily precipitations during the 18 months of sampling at La Montagne spring. When the daily precipitations reach $5.4 \mathrm{~mm}$ in April 2019, the water conductivity decreases until $1138 \mu \mathrm{S} . \mathrm{cm}^{-1}$ while the maximum of water conductivity during the months before was $1849 \mu{\mathrm{S} . \mathrm{cm}^{-1}}^{-}$. Since midOctober 2019 to February 2020, a rainy period occurred with daily precipitations high 
resulting in low conductivity $\left(<800 \mu \mathrm{S} . \mathrm{cm}^{-1}\right)$ except in mid-November. Considering the PCA (Figure 2), the samples of April 2019, October to December 2019, January and February 2020 correspond to samples associated with this period of low conductivity, increased precipitations (Figure 3) and also high concentrations of nitrates, phosphates, and sulphates (Figure 2). However, the correlation between conductivity and precipitations on sampling day indicates that the relationship between these two variables is low (Coefficient of determination: $\mathrm{R}^{2}=0.231$, $\mathrm{p}$-value $=0.043$ ).

\section{Influence of substrate on diatom communities' diversity}

A total of 201 diatom taxa were identified on the two sites (Supplementary data 1). Species richness was respectively 168 and 134 for La Montagne and Mariol springs. Average species richness on epipelic samples were respectively 15 and 11 species for La Montagne and Mariol while epilithic richness was respectively, 19 and 12 (Figure 4). The results of Wilcoxon test on species richness and on Shannon index indicate significant difference between mud (epipelon) and pebble (epilithon) (p-value<0.05) at La Montagne when no difference was detected at Mariol (p-value>0.05) (Figure 4). Diversity index allows to estimate the "uncaptured richness". Shannon-Wiener diversity index takes into account the species richness and the evenness of diatoms. It varies between 0 and 1: 0 corresponds to a community where one species is totally dominant and 1 to a community where each species has similar repartition (Figure 4). The results of Wilcoxon test on Evenness index show that there is significant difference between species due to differences of species abundances only at Mariol (Figure 4). At the two sites, 5 taxa had a relative abundance $>1 \%$. At Mariol, diatom assemblages were dominated by Planothidium frequentissimum Lange-Bertalot, Crenotia angustior (Grunow) Wojtal and Achnanthidium rivulare Potapova \& Ponader (Table 4). At La Montagne, the dominant species were Planothidium frequentissimum, $P$. lanceolatum (Brébisson ex Kützing) Lange-Bertalot, Humidophila perpusilla (Grunow) 
R.L.Lowe, Kociolek, J.R.Johansen, Van de Vijver, Lange-Bertalot \& Kopalová and Crenotia angustior (Table 4).

The nMDS (Figure 5) was performed based on ab.Jaccard matrix with species. Samples were projected in two dimensions and those with similar community structures are spatially close. Graphically, there is no clear distinction between the assemblages from pebble and mud. ANOSIM tests show a weak difference $(*: p \leq 0.05, * *: p \leq 0.01, * * * p \leq 0.001)$ between pebble and mud at La Montagne $(\mathrm{R}=0.28 * * *$ (jaccard) and $\mathrm{R}=0.32 * * *$ (ab.jaccard) $)$, and also a similar result was obtained at Mariol ( $\mathrm{R}=0.31 * * *$ (jaccard) and $0.25 * * *$ (ab.jaccard)). The Adonis tests (Table 5) considering La Montagne or Mariol springs and both were performed to determine the percentage of variability explained by each factor. Significance of the ADONIS test results was indicated by *: $\mathrm{p} \leq 0.05, * *: \mathrm{p} \leq 0.01, * * * \mathrm{p} \leq 0.001$. The analysis shows that the substrate factor contributed to $10.56 \% * * *$ (jaccard) or $30.72 \% * * *$ (ab.jaccard) of the variability at La Montagne, and 9.4\%*** (Jaccard) and 25.74\%** (ab.jaccard) at Mariol (Table 5). The contribution of season factor was $12.15 \% *$ (jaccard) and $14.30 \%$ (ab.jaccard) for La Montagne, and $8.5 \%$ (jaccard) and $8.39 \%$ (ab.jaccard) for Mariol. When the samples of Mariol and La Montagne were analysed together, location explained $10.14 \% * * *$ (jaccard) and 19.74\%*** (ab.jaccard) when substrate explained 6.14 \%*** (jaccard) and $18.47 \% * * *$ (with ab.jaccard) of the variability (Table 5). Percentages of contribution of seasonality are similar when analysis were performed with jaccard distances $(5.8 \% *)$ or ab.jaccard distance $(5.32 \%)$ (Table 5$)$.

\section{Discussion}

\section{Mariol and La Montagne are two different springs}

The environmental variables measured at La Montagne and Mariol springs clearly reveals the specificity of each spring which is in accordance with their origin (Figure 2). Mariol is 
characterised by high concentration of fluoride (Risler 1974). This observation is in line with the composition of the Vichy basin, where the fluoride concentration can reach 9 mg.L ${ }^{-1}$. The Vichy basin springs are originated from the same deep reservoir where the temperature is estimated at $135-150^{\circ} \mathrm{C}$ (Risler 1974). In contrast, higher carbonate concentrations are detected in La Montagne spring. This is a particularity of the Massif Central where there is a preponderance of bicarbonate rich waters (Risler 1974). Related to the high conductivity of La Montagne, this spring is more mineralised than Mariol. Considering the different variables, this last spring appears more stable. Indeed, the waters catchment in an elevated bowl leads to a more stable environment across the time at the spring emergence. At La Montagne, conductivity varies significantly over time linked to the precipitations. Indeed, when large episodes of precipitations as for example between October 2019 and February 2020 lead to decrease of conductivity due to spring water dilution. Furthermore, the increase of anthropogenic indicators $\left(\mathrm{NO}_{2}^{-}, \mathrm{NO}_{3}{ }^{-}, \mathrm{PO}_{4}{ }^{3-}\right)$ in the samples from October 2019 to February 2020 shows that La Montagne is affected by human activities. In fact, Châteldon is an area where there are some agricultural lands. The configuration of La Montagne site is favourable to the mixing of spring water and the watershed that hosts livestock farming. The watershed upstream of La Montagne emergence appears to have a great influence on its water. According to the observations and measures at the two springs, La Montagne and Mariol are two springs with different characteristics and represent two distinct biotopes.

\section{Substrate influence on richness}

In this study, two types of substrates were considered: epilithic communities were collected from pebble as hardened substrate, and epipelic communities from a mix of mud and litter (La Montagne) or a mix of travertine and litter (Mariol) as non-hardened. Previous works done on the influence of substrate on diatom communities suggest that specific richness was lower on pebble (Cantonati 1998; Cantonati and Spitale 2009; Lai et al. 2019b). However, at La 
Montagne the specific richness $(S)$ is higher on epilithic communities $(S=19)$ than epipelic ones $(\mathrm{S}=15)$ while it is similar on both substrates at Mariol. La Montagne and Mariol springs are two different biotopes with distinct configurations. As quoted before, La Montagne is a spring characterised by time-dependent physico-chemical properties due to disturbance by precipitations. The speculation that can be made is that in absence of great changes of physical and chemical parameters, species richness seems to be more similar between substrates. Otherwise, when the biotope is less stable, the richness is higher on hard substrate than on non-hardened ones. This can be related to the topography of the substrate. For example, in La Montagne mud can be more sensitive to the water flows than pebbles. Close relationship between richness and the degree of biotope disturbance is documented in the literature (Odum and Barrett 1971; Dudgeon et al. 2006; Cantonati et al.2012a). Additionally, there are more species at La Montagne than at Mariol which seems to be inconsistent with this last observation. In fact, heterogeneity of the environment is another parameter that needs to be take into account. Stable and homogeneous environment displays less diversity (Ramade 2009). At Mariol, the absence of fluctuations of physical and chemical variables and its configuration suggest that this spring represents a stable and homogeneous biotope. This can explain the lower diversity observed at this spring.

\section{Substrate influence on diatom communities}

At La Montagne spring, the diatom communities were mostly dominated by Planothidium frequentissimum, Humidophila perpusilla, Crenotia angustior and P. lanceolatum.

Planothidium frequentissimum and C. angustior were also dominant at Mariol with Achnanthidium rivulare. The two springs show similarities through their dominant species. When studying the diatom communities of some springs in Auvergne (France) and Sardinia (Italy), Lai et al. (2019a) reported that P. frequentissimum was found in others springs of Auvergne and was also counted among the most abundant species in some of them. Crenotia 
angustior was present in springs of Europe like the Mofette spring which is in the south of Poland (Noga et al. 2018). Humidophila perpusilla colonised environment with low light intensity (Lange-Bertalot et al. 2017). Achnanthidium rivulare has affinity for water with relatively low calcium and high chloride concentrations (Potapova and Ponader 2004). Achnanthidium rivulare have different ecological preferences but are abundant in rivers with low-alkalinity and low phosphorus concentration (Potapova and Ponader 2004; LangeBertalot et al. 2017).

The nMDS was done on a dissimilarity matrix based on ab.jaccard index. No clear distinction of substrate samples was observed. In agreement with this result, the ANOSIM analyses completed with samples from the springs, show that there is a low difference between samples from different substrates. These results are similar to Potapova and Charles (2005) that demonstrates that algal assemblages are similar on hard substrate (rocks and wood) and soft substrates (sediments) in 551 Russian rivers samples. Stevenson and Hashim (1989) also demonstrate that there is no significant difference between epipelic, epipsammic and epiphytic diatom communities of two rivers in northern Michigan.

The Adonis test that consists in a permutation multivariate ANOVA (PMANOVA) completes the first results and determines which factors explain the best the communities variability. Location and season which are spatial and temporal factors known to influence the diversity were taken into account in a same ADONIS test. Jaccard dissimilarity index is used to compare taxonomic composition of two assemblages of community. Its operates with the number of species shared between the two assemblages and the number of unique species of each assemblage. The ab.jaccard distances (or Chao.jaccard) considers not only the taxonomic composition but also the species abundances and thus, evaluates similarities between samples diversity. Considering only the taxonomic composition of samples, substrate explained 6.14 $\%$ of the variance when location explained $10.1 \%$. Location is the factor that better explained 
the difference of diatom assemblages composition between springs. As mentioned above, physical and chemical variables are different at Mariol and La Montagne springs making two different biotopes (Figure 2). The link between the PCA and the Adonis test suggests that environmental variables of the studied sites explained more the variability of diatom assemblages than the type of substrate. Cantonati and Spitale (2009) observed that environmental parameters explain $42 \%$ of the diatom assemblage variabilities when substrate explains only $3 \%$. The sampling of 21 springs and streams in this study increases the statistical power and allows to conclude that macrohabitat which is the ecosystem's location and its abiotic factors have more impact on the variability of diatom assemblages than microhabitat such as the substrate type. Several studies have shown that environmental and spatial variables have more influence on diatom community variations than substrate (Soininen et al. 2004; Soininen 2007). Moreover, Sabater and Roca (1990) concluded that ionic composition of springs is the major factors that determine diatoms diversity as well as temperature, conductivity, alkalinity that reinforcing the results. Season is the parameter that explains the variability the least well. Same conclusion was reached when Moresco and Rodrigues (2014) analysed periphytic diatoms of two Brazilian streams. The addition of species abundances allows the consideration of abundant and rare species in the samples dissimilarity computation. Interestingly, in this case, substrate explained $18.74 \%$ and location $19.74 \%$ of the variability. The percentage of contribution of each of these two factors increases with the addition of species abundances but location remains the factor than explains the most the variability between diatoms communities. Also, the contribution percentages of these two factors became closer. This suggests that substrate can explain the difference between diatom communities' diversity as much as location. Townsend (2005) observed that communities were similar between rock and sand but abundances were different according to the substrate. These results suggest that substrate have less impact on diatom 
communities composition than location but have influence on species abundances. The comparison of species distributions at each site allowed to estimate the contribution of season and substrate in diatom communities' distribution.

However, several studies reported that species richness is higher during spring and summer. But others assume less seasonal effect (Cantonati and Pipp 2000). Seasonal effects on benthic diatoms were studied in river and lead to the conclusion that the change of river flow related to season affects diatoms community (Martínez de Fabricius et al. 2003). At La Montagne, seasonal effect was higher than at Mariol particularly with the jaccard index. Seasonality seems contribute more than substrate to diatom assemblages composition. This could be related to the disturbance of La Montagne water by precipitations. The relation between precipitation frequency and season can explain the result that was obtained with the Adonis test. When comparing communities by taking account of the species abundances, season didn't contribute more than substrate to diatoms community structuration. This observation is similar for the two springs studied.

\section{Conclusion}

La Montagne and Mariol springs are two different biotopes and this is reflected in their diatom communities composition. Their physico-chemical particularities are linked to the geological origin of the underground water. Mariol is a more stable spring than La Montagne due to the absence of great fluctuations of physical parameters. In contrast, La Montagne spring shows conductivities that highly vary due to precipitations. Thus, this spring shows less stability of its waters. At La Montagne and Mariol springs, low difference between epipelic and epilithic diatom communities is underlined. The variability of composition in diatom communities was better explained by the factor (location). When comparing the diversity of diatom communities, location is the factor that explained most of the variabilities between communities. Thus, environmental variables (summarised by Location) have 
significantly higher importance as drivers of diatom taxonomic composition than season and substrate, but the substrate seems to have influence on the species abundances as much as the location.

\section{Acknowledgements}

This study was funded by a grant from the Centre National de la Recherche Scientifique (CNRS, NEEDS, project Acronym: DISCOVER). L.A.B. was supported by a Ph. D. grant from the CNRS. Funding for this research was partly provided to C.E.W. and L.E. in the framework of the project DIATOMS (LIST - Luxembourg Institute of Science and Technology). We acknowledge financial support from CNRS-INEE within the context of the Zone Atelier Territoires Uranifères. We also acknowledge the anonymous reviewer and Patrick Gasqui (INRAE, UR EpiA - Unité de Recherche d'Épidémiologie Animale, France) for their help and advises for the statistical analyses of the results.

\section{Disclosure statement}

No potential conflict of interest was reported by the authors.

\section{References}

Abdi H. and Williams LJ. 2010. Principal Component Analysis. Wiley Interdiscip. Rev. Comput. Stat. 2(4): 433-459. doi:10.1002/wics.101

Cantonati M. 1998. Diatom communities of springs in the southern Alps. Diatom Res. 13(2): 201-220. doi:10.1080/0269249X.1998.9705449

Cantonati M, Pipp E. 2000. Longitudinal and seasonal differentiation of epilithic diatom communities in the uppermost sections of two mountain spring-fed streams. Verh Internat Verein Theor Angew Limnol. 27(3): 1591-1595. doi:10.1080/03680770.1998.11901507

Cantonati M, Spitale D. 2009. The role of environmental variables in structuring epiphytic and epilithic diatom assemblages in springs and streams of the Dolomiti Bellunesi National Park (south-eastern Alps). Fundam Appl Limnol. 174(2): 117-133. doi:10.1127/1863$\underline{9135 / 2009 / 0174-0117}$ 
Cantonati M, Gerecke R, Bertuzzi E. 2009. Springs of the Alps - sensitive ecosystems to environmental change: from biodiversity assessments to long-term studies. Hydrobiologia. 562: 59-96. doi:10.1007/s10750-005-1806-9

Cantonati M, Füreder L, Gerecke R, Jüttner I, Cox EJ. 2012a. Crenic habitats, hotspots for freshwater biodiversity conservation: toward an understanding of their ecology. Freshw Sci. 31(2): 463-480. doi:10.1899/11-111.1

Cantonati M, Angeli N, Bertuzzi E, Spitale D, Lange-Bertalot H. 2012b. Diatoms in springs of the Alps: spring types, environmental determinants, and substratum. Freshw Sci. 31(2):499524. doi:10.1899/11-065.1

Chao A, Chazdon RL, Colwell RK, Shen TJ. 2006. Abundance-based similarity indices and their estimation when there are unseen species in samples. Biometrics. 62(2): 361-371. doi:10.1111/j.1541-0420.2005.00489.x

Clarke KR. 1993. "Non-parametric multivariate analyses of changes in community structure". Austral Ecol.. 18 (1): 117-143. doi:10.1111/j.1442-9993.1993.tb00438.x

Cox EJ. 1988. Has the role of the substratum been underestimated for algal distribution patterns in freshwater ecosystems? Biofouling. 1(1): 49-63. doi:10.1080/08927018809378095

Douglas B. 1958. The ecology of the attached diatoms and other algae in a small stony stream. J Ecol. 46(2): 295-322. doi:10.2307/2257397

Dray S, Pélissier R, Couteron P, Fortin MJ, Legendre P, Peres-Neto PR, Bellier E, Bivand R, Blanchet FG, De Caceres M, Dufour AB, Heegaard E, Jombart T, Munoz F, Oksanen J, Thioulouse J, Wagner, H. H. 2012. Community ecology in the age of multivariate multiscale spatial analysis. Ecol Monogr. 82(3): 257-275. doi:10.1890\%2F11-1183.1

Dudgeon D, Arthington AH, Gessner MO, Kawabata Z-I, Knowler DJ, Lévêque C, Naiman RJ, Prieur-Richard A-H, Soto D, Stiassny MLJ, Sullivan CA. 2006. Freshwater biodiversity: importance, threats, status and conservation challenges. Biol Rev. 81(2): 163-182. doi:10.1017/S1464793105006950

Hofmann G, Lange-Bertalot H, Werum M. 2013. Diatomeen im Süßwasser-Benthos von Mitteleuropa: 2 Corrected Edition. Königstein: Koeltz Scientific Books. 
Jaccard P. 1901. Distribution de la flore alpine dans le Bassin des Dranses et dans quelques régions voisines. Bull Soc Vaudoise Sci Nat. 37: 241-272. doi: $\underline{10.5169 / s e a l s-266440}$

Jüttner I, Rothfritz H, Ormerod S. 1996. Diatoms as indicators of river quality in the Nepalese Middle Hills with consideration of the effects of habitat-specific sampling. Freshw Biol. 36(2): 475-486. doi:10.1046/j.1365-2427.1996.00101.x

Krammer K. 2000. Diatoms of Europe. Vol. 1: The Genus Pinnularia. Königstein: A.R.G. Gantner Verlag Kommanditgesellschaft.

Krammer K. 2002. Diatoms of Europe, Vol. 3: Cymbella. Königstein: A.R.G. Gantner Verlag Kommanditgesellschaft.

Krammer K. 2003. Diatoms of Europe; Vol.4: Cymbopleura, Delicata, Navicymbula, Gomphocymbellopsis, Afrocymbella. Königstein: A.R.G. Gantner Verlag Kommanditgesellschaft

Krammer K, Lange-Bertalot H. 1997a. Bacillariophyceae. 1. Teil: Naviculaceae. In: Ettl H., Gerloff J., Heynig H. \& Mollenhauer D. (eds.), Süsswasserflora von Mitteleuropa, 2(1), 2th ed. Stuttgart: Spektrum Akademischer Verlag, Heidelberg.

Krammer K, Lange-Bertalot H. 1997b. Bacillariophyceae. 2. Teil: Bacillariaceae, Epithemiaceae, Surirellaceae. In: Ettl H., Gerloff J., Heynig H. \& Mollenhauer D. (eds.), Süsswasserflora von Mitteleuropa, 2(2), 2th ed. Stuttgart: Spektrum Akademischer Verlag, Heidelberg.

Krammer K, Lange-Bertalot H. 2000a. Bacillariophyceae. 3. Teil: Centrales, Fragilariaceae, Eunotiae. In: Ettl H., Gerloff J., Heynig H. \& Mollenhauer D. (eds.), Süsswasserflora von Mitteleuropa, 2 (3), 2th ed. Stuttgart: Spektrum Akademischer Verlag, Heidelberg.

Krammer K, Lange-Bertalot H. 2000b. Bacillariophyceae. 5. Teil: English and French translation of the keys. In: Büdel B., Gärtner G., Krienitz L. \& Lokhorst G.M. (eds.), Süsswasserflora von Mitteleuropa, 2(5), Stuttgart: Spektrum Akademischer Verlag, Heidelberg.

Krammer K, Lange-Bertalot H. 2004. Bacillariophyceae. 4. Teil: Achnanthaceae, kritische Ergänzungen zu Navicula (Lineoatae) und Gomphonema. In: Ettl H., Gärtner G., Heynig H. \& 
Mollenhauer D. (eds.), Süsswasserflora von Mitteleuropa, 2(4), 2th ed. Spektrum Akademischer Verlag, Heidelberg.

Kresic N. 2010. Types and classifications of springs. In: Kresic N, Stevanovic Z. (Eds) Groundwater Hydrology of Springs. Butterworth-Heinemann. Pages 31-85. doi:10.1016/B978$\underline{1-85617-502-9.00002-5}$

Kulikovskiy MS, Lange-Bertalot H, Witkowski A, Dorofeyuk NI, Genkal SI. 2010. Diatom assemblages from Sphagnum bogs of the world. I. Nur bog in northern Mongolia. In: Biblioth Diatomol. Vol. 55:1-326. J. Cramer. Germany: Gebrüder Borntraeger Verlag.

Lai GG, Beauger A, Wetzel CE, Padedda BM, Voldoire O, Lugliè A, Allain E, Ector L. 2019a. Diversity, ecology and distribution of benthic diatoms in thermo-mineral springs in Auvergne (France) and Sardinia (Italy). PeerJ. 7: e7238. doi:10.7717/Fpeerj.7238

Lai GG, Padedda BM, Wetzel CE, Cantonati M, Sechi N, Lugliè A, Ector L. 2019b. Diatom assemblages from different substrates of the Casteldoria thermo-mineral spring (Northern Sardinia, Italy). Bot Lett. 166(1): 14-31. doi:10.1080/23818107.2018.1466726

Lange-Bertalot H. 2001. Navicula sensu stricto, 10 Genera separated from Navicula sensu lato Frustulia. Diatoms of Europe. 2. 1-526. Königstein: A.R.G. Gantner Verlag Kommanditgesellschaft.

Lange-Bertalot H, Hofmann G, Werum M, Cantonati M. 2017. Freshwater Benthic Diatoms of Central Europe: Over 800 Common Species Used in Ecological Assessment. English edition with updated taxonomy and added species. 1-942. Schmitten-Oberreifenberg: Koeltz Botanical Books.

Malavoi JR., Souchon Y. 2002. Description standardisée des principaux faciès d'écoulement observables en rivière : clé de détermination qualitative et mesures physiques. Bulletin Français de Pêche et de Pisciculture 365-366 : 357-372.

Mann DG, Droop SJM. 1996. Biodiversity, biogeography and conservation of diatoms. Hydrobiologia. 336: 19-32. Doi:10.1007/BF00010816 
Martínez de Fabricius AL, Maidana N, Gómez N, Sabater S. 2003. Distribution patterns of benthic diatoms in a Pampean river exposed to seasonal floods: the Cuarto River (Argentina). Biodivers Conserv. 12: 2443-2454. doi:10.1023/A:1025857715437

Medlin LK, Juggins S. 2018. Multivariate analyses document host specificity, differences in the diatom metaphyton vs. epiphyton, and seasonality that structure the epiphytic diatom community. Estuar Coast Shelf Sci. 213: 314-330. doi:10.1016/j.ecss.2018.06.011

Millie DF, Lowe RL. 1983. Studies on Lake Erie's littoral algae; Host specificity and temporal periodicity of epiphytic diatoms. Hydrobiologia. 99: 7-18. doi:10.1007/BF00013712

Moresco C, Rodrigues L. 2014. Periphytic diatom as bioindicators in urban and rural streams. Acta Sci Biol Sci. 36(1): 67-78. doi: $10.4025 /$ actascibiolsci.v36i1.18175

Noga T, Rybak M, Peszek L, Poradowska A, Kochman-Keędziora N, Solak C. 2018. Mofette spring - unusual environment for microbial life on the example of diatoms. Poster session presented at: 13th International Symposium on Fisheries and Aquatic Sciences (FABA 2018), in Ankara, Turkey.

Odum E, Barrett GW. 1971. Fundamentals of Ecology. Fifth edition., Belmont: Thomson Brooks/Cole CA.

O'Quinn R, Sullivan MJ. 1983. Community structure dynamics of epilithic and epiphytic diatoms in a Mississippi stream. J Phycol. 19(2): 123-128. doi: 10.1111/j.0022$\underline{3646.1983 .00123 . x}$

Patrick R. 1977. Ecology of freshwater diatoms and diatom communities. In: Werner D, editor. The Biology of Diatoms. Botanical monographs 13. California: Blackwell Scientific Publications. P.284-332.

Potapova M, Charles DF. 2005. Choice of substrate in algae-based water-quality assessment. Freshw Sci. 24(2): 415-427. doi:10.1899/03-111.1

Potapova MG, Ponader KC. 2004. Two common north American diatoms, Achnanthidium rivulare sp. nov. and A. deflexum (reReimer) Kingston: Morphology, ecology and comparison with related species. Diatom Res. 19 (1):33-57. doi:10.1080/0269249X.2004.9705606 
Prygiel J, Coste M. 2000. Guide méthodologique pour la mise en œuvre de l'Indice Biologique Diatomées NF T 90-354. Etude Agences de l'Eau-Cemagref Bordeaux, Agences de 1'Eau: Douai, France.

Ramade F. 2009. Ecologie fondamentale-Eléments d'écologie. $4^{\mathrm{e}}$ édition. Paris : Dunod.

Risler JJ. 1974. Description et classification géologique des sources minérales et thermales du Massif Central. Description and geological classification of the mineral and thermal springs of the Massif Central. Report No : B.R.G.M. 74-SGN-418 MCE. Orléans : Bureau de Recherches Géologiques et Minières, Service des eaux minérales et thermales.

Round FE. 1991. Diatoms in river water-monitoring studies. J Appl Phycol. 3: 129-145. doi:10.1007/BF00003695

Sabater S, Roca JR. 1990. Some factors affecting distribution of diatom assemblages in Pyrenean springs. Freshw. Biol. 24(3): 493-507. doi:10.1111/j.1365-2427.1990.tb00727.x

Sabater S, Gregory SV, Sedell JR. 1998. Community dynamics and metabolism of benthic algae colonizing wood and rock substrata in a forest stream. J Phycol. 34(4): 561-567. doi:10.1046/j.1529-8817.1998.340561.x

Soininen J. 2007. Environmental and spatial control of freshwater diatoms - A review. Diatom Res. 22(2) : 473-490. doi:10.1080/0269249X.2007.9705724

Soininen J, Paavola R, Muotka T. 2004. Benthic diatom communities in boreal streams: community structure in relation to environmental and spatial gradients. Ecography. 27: 330342. doi:10.1111/j.0906-7590.2004.03749.x

Stevenson RJ, Hashim S. 1989. Variation in diatom community structure among habitats in sandy streams. J Phycol. 25(4): 678-686. doi:10.1111/j.0022-3646.1989.00678.x

Sullivan MJ. 1982. Similarity of an epiphytic and edaphic diatom community associated with Spartina alterniflora. Trans Am Micros Soc. 101(1): 84-90. doi:10.2307/3225573

Townsend SA, Gell PA. 2005. The role of substrate type on benthic diatom assemblages in the Daly and Roper Rivers of the Australian wet/dry tropics. Hydrobiologia. 548: 101-115. doi: $10.1007 / \mathrm{s} 10750-005-0828-7$ 
Wetzel CE, Ector L, Van de Vijver B, Compère P, Mann DG. 2015. Morphology, typification and critical analysis of some ecologically important small naviculoid species (Bacillariophyta). Fottea. 15(2): 203-234. doi:10.5507/fot.2015.020

Wojtal AZ, Sobczyk L. 2012. The influence of substrates and physicochemical factors on the composition of diatom assemblages in karst springs and their applicability in water-quality assessment. Hydrobiologia. 695: 97-108. doi:10.1007/s10750-012-1203-0

Table 1. Physical variables (mean \pm SD) for La Montagne and Mariol springs considering the 18 months sampled.

Table 2. Concentrations (mg. $\left.\mathrm{L}^{-1}\right)$ of ions (indicators of deep water and geological nature) (mean $\pm \mathrm{SD})$ for each site.

Table 3. Concentration (mg. $\left.\mathrm{L}^{-1}\right)$ of pollutant ions (mean $\pm \mathrm{SD}$ ) for each site.

Table 4. Relative abundances of the dominant species with an abundance $>1 \%$ in at least one sample for Mariol and La Montagne springs.

Table 5. NPMANOVA (Adonis) results for unifactorial analysis of substrate, location and season variables made with Jaccard and ab.jaccard distances for Montagne and Mariol springs or the springs together performed on taxa with an abundance $>1 \%$ in at least one sample. The significance of the results is indicated by $(*) \mathrm{p}<0.05,(* *) \mathrm{p}<0.01,(* * *) \mathrm{p}<0.001$.

Supplementary Table 1. Species list of diatoms at Mariol and La Montagne springs.

Figure 1. Location (a) in France of the two mineral springs studied in Auvergne Region (b): Mariol (c) and La Montagne (d, e).

Figure 2. Principal component analysis (PCA) shows the samples distribution based on physical and chemical variables of the Mariol and La Montagne site, monitored from July 2018 until June 2020. The Kruskal-Wallis test based on Cartesian coordinates of the samples points of the PCA validate statistical difference between samples of Mariol and La Montagne by the axis $2(\mathrm{p}<0.0001)$.

Figure 3. Evolution of the daily precipitations and of water conductivity for the La Montagne mineral spring. 
Figure 4. Boxplot showing results of (A) Species richness, (B) Shannon, (C) Evenness diversity index calculation for diatom for two substrates (Epilithon or Epipelon) communities at Mariol and La Montagne. Wilcoxon test: **: $p<0.05,{ }^{* *}: \mathrm{p}<0.005$, NS: non-significant.

Figure 5. Non-metric multidimensional scaling (nMDS) ordination plot based on species composition of diatom communities for two substrates (Epilithon or Epipelon) at Mariol and La Montagne springs. The matrix distances is based on ab.jaccard distances.

\section{Figures:}

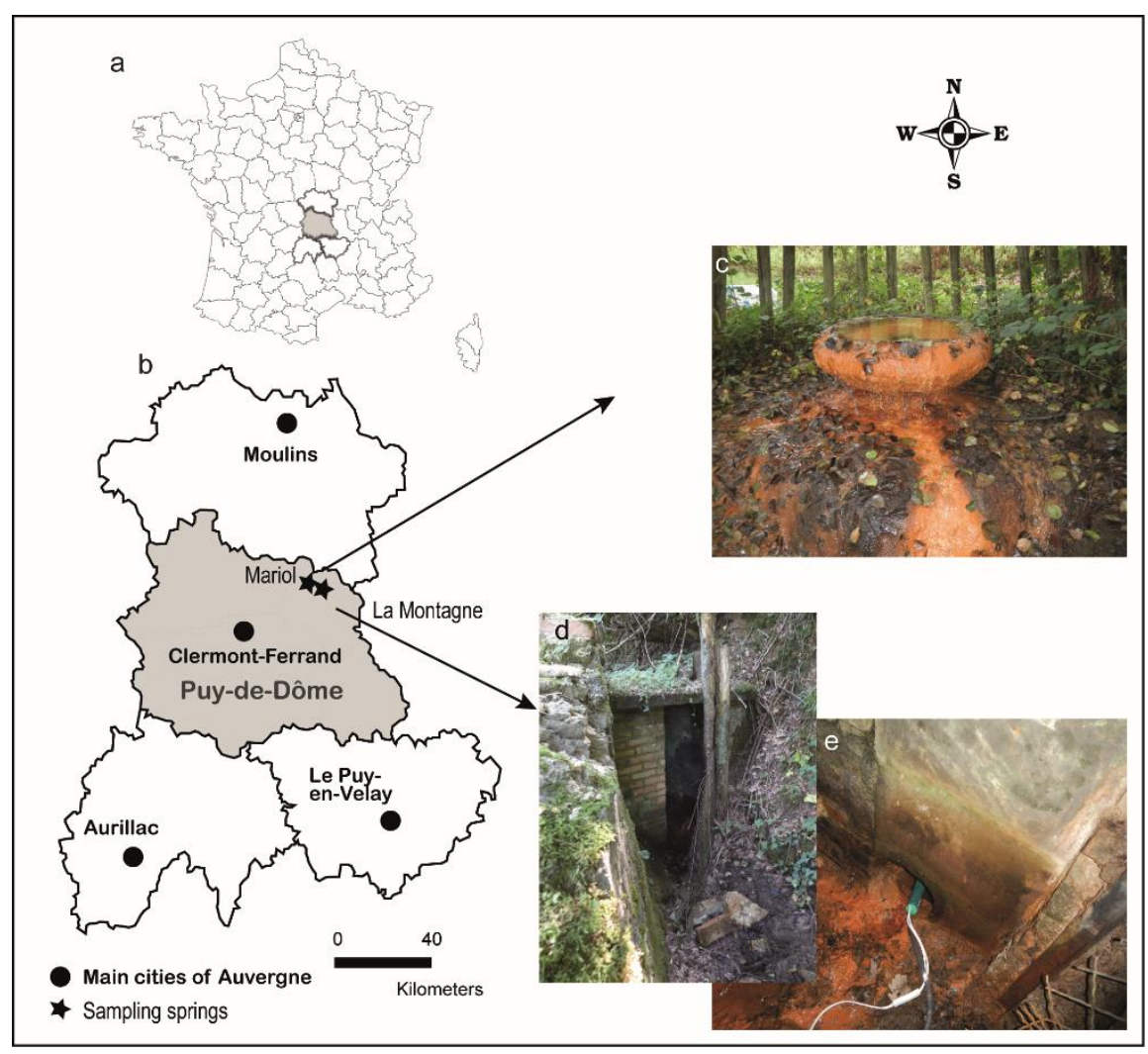

Figure 1. Location (a) in France of the two mineral springs studied in Auvergne Region (b): Mariol (c) and La Montagne $(\mathrm{d}, \mathrm{e})$. 


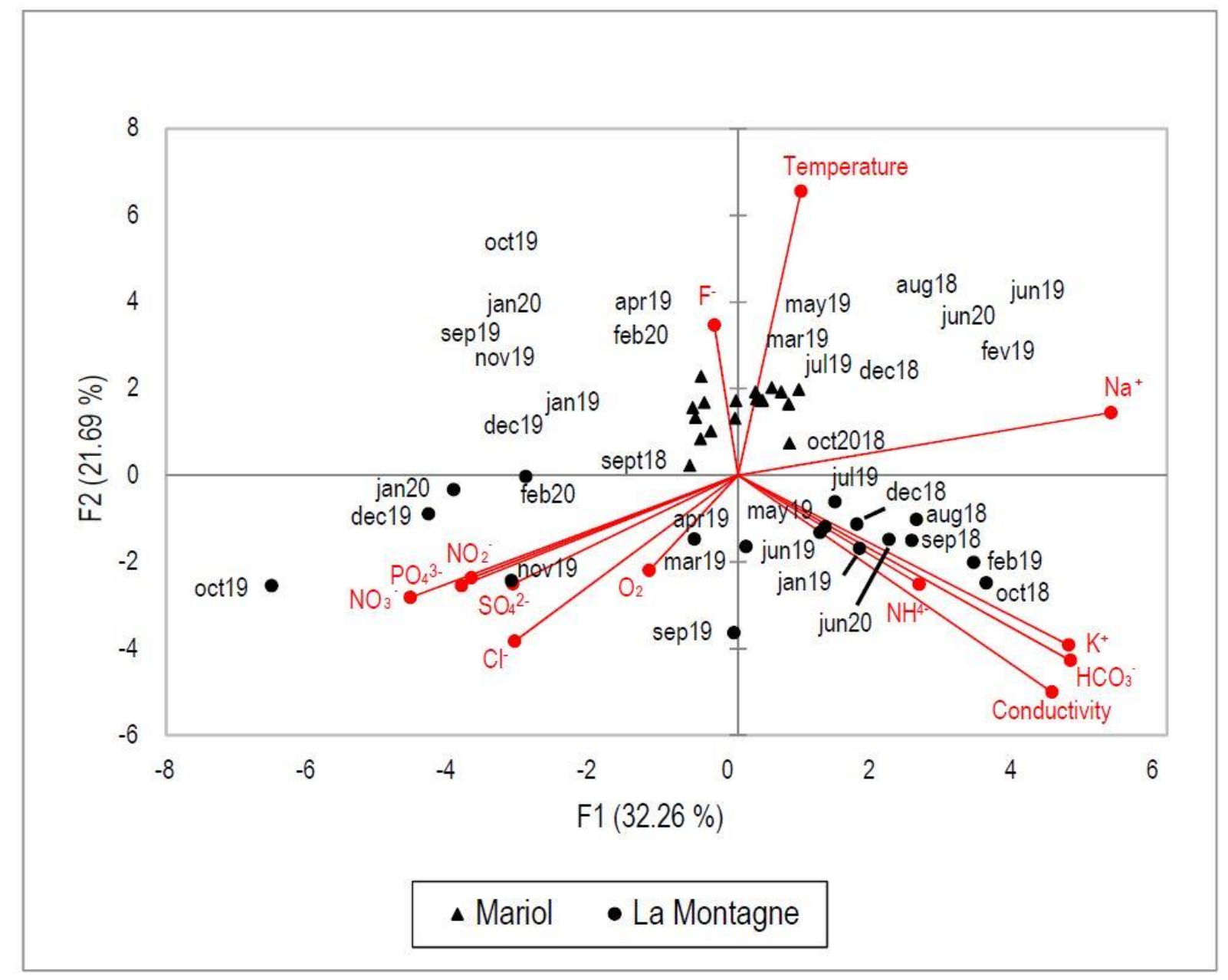

Figure 2. Principal component analysis (PCA) shows the samples distribution based on physical and chemical variables of the Mariol and La Montagne site, monitored from July 2018 until June 2020. The Kruskal-Wallis test based on Cartesian coordinates of the samples points of the PCA validate statistical difference between samples of Mariol and La Montagne by the axis $2(\mathrm{p}<0.0001)$. 


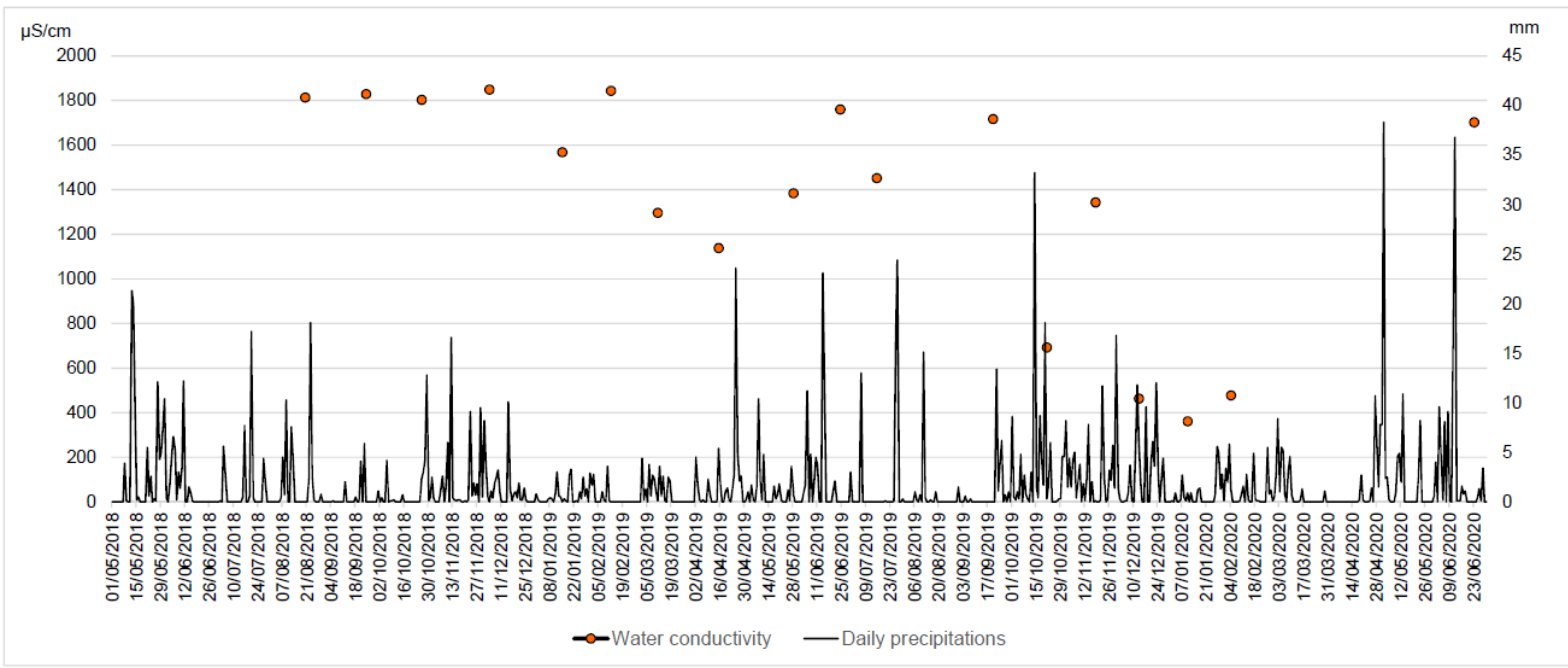

Figure 3. Evolution of the daily precipitations and of water conductivity for the La Montagne mineral spring.

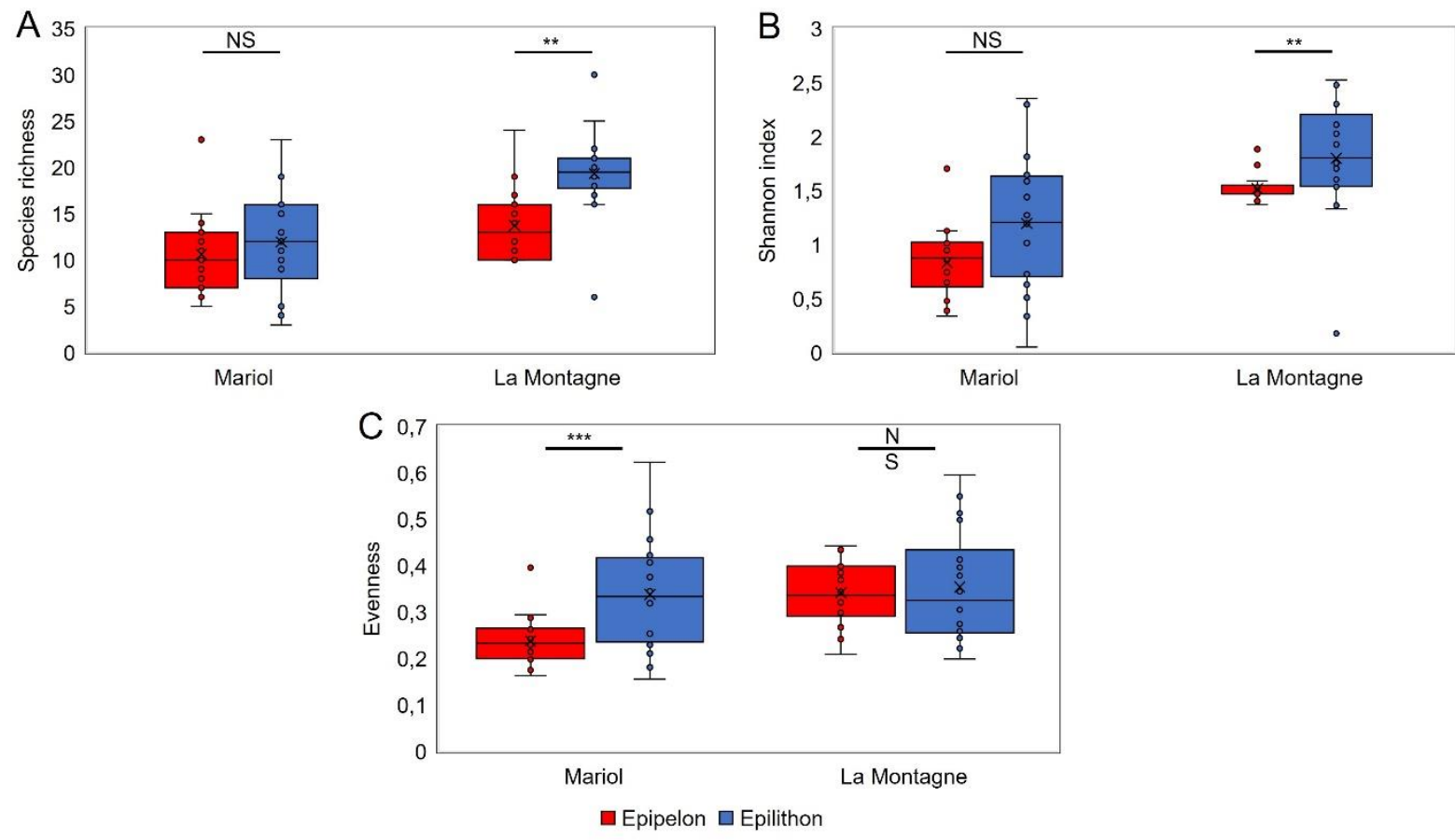

Figure 4. Boxplot showing (A) Species richness, (B) Shannon, and (C) Evenness diversity index for diatom communities living on two substrates (Epipelon (red) or Epilithon (blue)) at Mariol and La Montagne. Wilcoxon test: **: p<0.05, ***: p<0.005, NS: non-significant. 


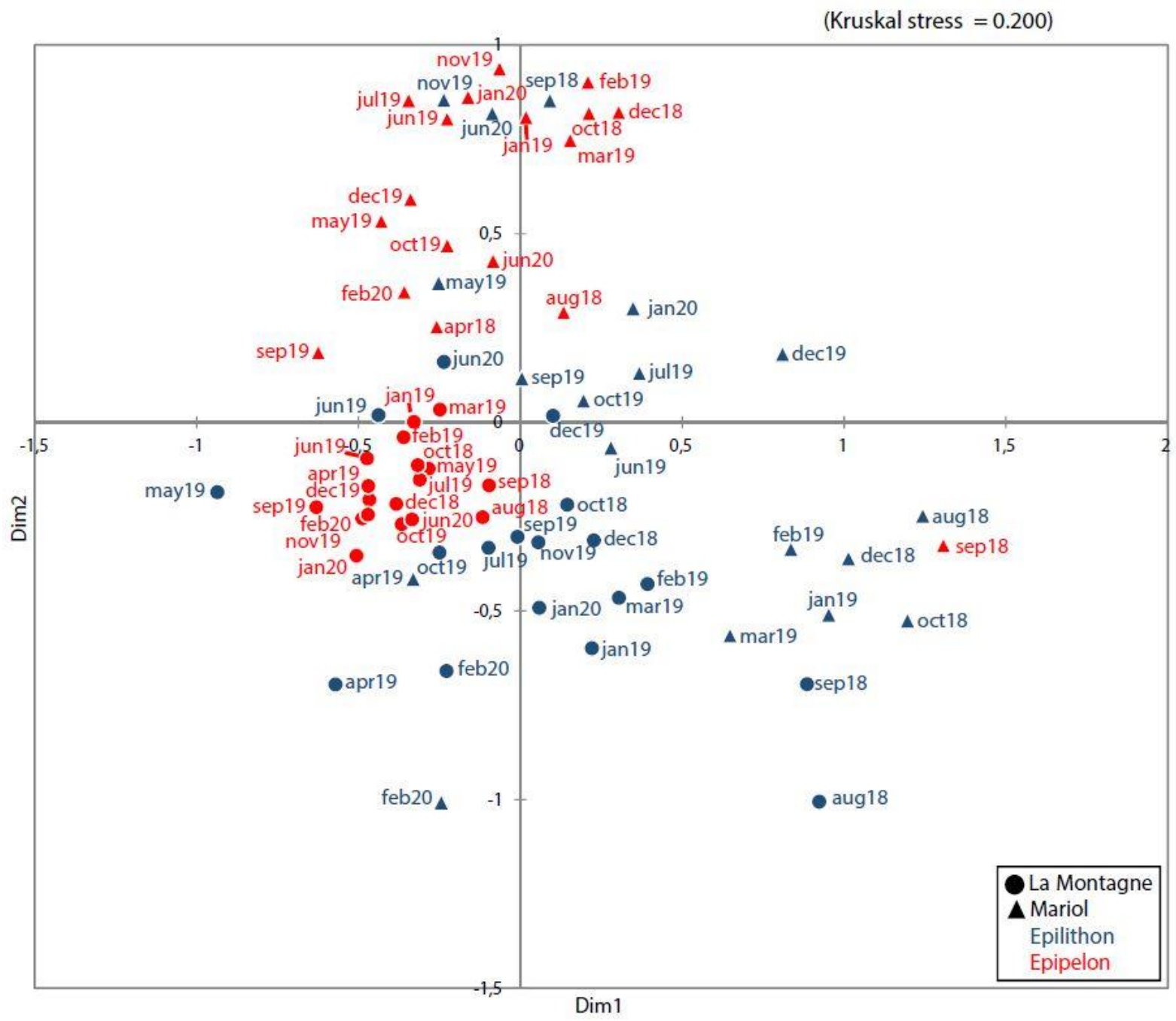

Figure 5. Non-metric multidimensional scaling (nMDS) ordination plot based on species composition of diatom communities for two substrates (Epilithon (blue) or Epipelon (red)) at Mariol and La Montagne springs. The matrix distances is based on ab.jaccard distances. 


\section{Tables:}

Table 1. Physical variables (mean \pm SD) for La Montagne and Mariol springs considering the 18 months sampled.

\begin{tabular}{ccccc}
\hline Sites & Conductivity $\left(\mu \mathrm{S} . \mathrm{cm}^{-1}\right)$ & $\mathbf{p H}(\mathbf{p H}$ unit) & Dissolved oxygen (\%) & Temperature $\left({ }^{\circ} \mathrm{C}\right)$ \\
\hline La Montagne & $1342.25 \pm 541.48$ & $6.47 \pm 0.12$ & $4.15 \pm 3.04$ & $17.03 \pm 0.35$ \\
\hline Mariol & $842.85 \pm 70.09$ & $6.40 \pm 0.11$ & $14.37 \pm 14.60$ & $11.50 \pm 1.48$ \\
\hline
\end{tabular}

Table 2. Concentrations (mg. $\left.\mathrm{L}^{-1}\right)$ of ions (indicators of deep water and geological nature) (mean $\pm \mathrm{SD}$ ) for each site.

\begin{tabular}{|c|c|c|c|c|c|c|c|}
\hline Sites & $\mathrm{Li}^{2+}$ & $\mathrm{Na}^{+}$ & $\mathbf{K}^{+}$ & $\mathrm{Mg}^{2+}$ & $\mathrm{Ca}^{2+}$ & $F^{-}$ & $\mathrm{HCO}_{3}^{-}$ \\
\hline La Montagne & $0.59 \pm 0.59$ & $118.56 \pm 55.81$ & $16.23 \pm 8.29$ & $27.92 \pm 17.48$ & $153.70 \pm 74.67$ & $1.38 \pm 0.58$ & $822.83 \pm 410.06$ \\
\hline Mariol & $0.51 \pm 0.02$ & $144.87 \pm 7.15$ & $10.80 \pm 2.69$ & $4.01 \pm 0.44$ & $33.00 \pm 3.33$ & $4.75 \pm 0.43$ & $504.61 \pm 54.15$ \\
\hline
\end{tabular}

Table 3. Concentration $\left(\mathrm{mg} . \mathrm{L}^{-1}\right)$ of pollutant ions (mean $\pm \mathrm{SD}$ ) for each site.

\begin{tabular}{|c|c|c|c|c|c|c|}
\hline Sites & $\mathrm{Cl}^{-}$ & $\mathrm{NH}_{4}^{+}$ & $\mathrm{NO}_{2}^{-}$ & $\mathrm{NO}_{3}^{-}$ & $\mathrm{PO}_{4}{ }^{3-}$ & $\mathrm{SO}_{4}{ }^{2-}$ \\
\hline La Montagne & $8.93 \pm 9.00$ & $0.34 \pm 0.40$ & $0.02 \pm 0.00$ & $3.41 \pm 4.93$ & $0.11 \pm 0.07$ & $12.31 \pm 4.05$ \\
\hline Mariol & $2.82 \pm 0.71$ & $0.40 \pm 0.37$ & $0.02 \pm 0.01$ & $0.08 \pm 0.05$ & $0.04 \pm 0.01$ & $6.73 \pm 0.48$ \\
\hline
\end{tabular}


Table 4. Relative abundances of the dominant species with an abundance $>1 \%$ in at least one sample for Mariol and La Montagne springs.

\begin{tabular}{ccccc}
\hline & \multicolumn{2}{c}{ La Montagne } & \multicolumn{2}{c}{ Mariol } \\
\hline Species & Epipelon & Epilithon & Epipelon & Epilithon \\
\hline Achnanthidium rivulare & - & - & - & $12.0 \%$ \\
\hline Crenotia angustior & $17.0 \%$ & $21.1 \%$ & $17.0 \%$ & $4.4 \%$ \\
\hline Humidophila perpusilla & $23.0 \%$ & $11.3 \%$ & - & - \\
\hline Planothidium frequentissimum & $45.4 \%$ & $11.3 \%$ & $71.6 \%$ & $40.0 \%$ \\
\hline Planothidium lanceolatum & $3.7 \%$ & - & - & - \\
\hline
\end{tabular}


Table 5. NPMANOVA (Adonis) results for unifactorial analysis of substrate, location and season variables made with Jaccard (JD) and ab.jaccard (ab.J) distances for Montagne and Mariol springs or the springs together performed on taxa with an abundance $>1 \%$ in at least one sample. The significance of the results is indicated by $(*) \mathrm{p}<0.05,(* *) \mathrm{p}<0.01,(* * *) \mathrm{p}<0.001$.

\begin{tabular}{|c|c|c|c|c|c|c|}
\hline \multirow[t]{2}{*}{ Sites } & \multicolumn{2}{|c|}{ La Montagne and Mariol } & \multicolumn{2}{|c|}{ La Montagne } & \multicolumn{2}{|c|}{ Mariol } \\
\hline & $R^{2}(J)$ & $R^{2}(a b . J)$ & $R^{2}(J)$ & $R^{2}$ (ab.J) & $R^{2}(J)$ & $R^{2}$ (ab.J) \\
\hline Substrate ( 2 modalities) & $6.14 \% * * *$ & $18.47 \% * * *$ & $10.56 \% * * *$ & $30.72 \% * * *$ & $9.4 \% * * *$ & $25.74 \% * *$ \\
\hline Season (4 modalities) & $5.85 \% *$ & $5.32 \%$ & $12.15 \% *$ & $14.30 \%$ & $8.5 \%$ & $8.39 \%$ \\
\hline Location ( 2 modalities) & $10.14 \% * * *$ & $19.74 \% * * *$ & - & & - & \\
\hline
\end{tabular}


2 Supplementary data 1. Species list of diatoms at Mariol and La Montagne springs.

\begin{tabular}{|c|c|c|c|c|}
\hline & \multicolumn{2}{|c|}{ La Montagne } & \multicolumn{2}{|c|}{ Mariol } \\
\hline & Epipelon & Epilithon & Epipelon & Epilithon \\
\hline Achnanthidium eutrophilum (Lange-Bert.) Lange-Bert. & $\mathbf{x}$ & & $\mathbf{x}$ & $\mathbf{x}$ \\
\hline Achnanthidium cf. eutrophilum (Lange-Bert.) Lange-Bert. & $\mathbf{x}$ & & & \\
\hline Achnanthidium microcephalum Kütz. & $\mathbf{x}$ & & $\mathbf{x}$ & $\mathrm{x}$ \\
\hline Achnanthidium aff. microcephalum Kütz. & & $\mathbf{x}$ & & \\
\hline Achnanthidium cf. nanum (F.Meister) Novais \& Jüttner in Novais et al. & $\mathbf{x}$ & & & \\
\hline Achnanthidium rivulare Potapova \& Ponader & $\mathbf{x}$ & $\mathbf{x}$ & $\mathbf{x}$ & $\mathbf{x}$ \\
\hline Achnanthidium subhudsonis var. kraeuselii (Cholnoky) Cantonati \& Lange-Bert. in Kusber et al. & $\mathbf{x}$ & $\mathbf{x}$ & $\mathbf{x}$ & \\
\hline Achnanthidium sp. & $\mathbf{x}$ & $\mathbf{x}$ & & \\
\hline Achnanthidium sp. 2 & $\mathbf{x}$ & $\mathbf{x}$ & $\mathbf{x}$ & $\mathbf{x}$ \\
\hline Adlafia minuscula var. muralis (Grunow) Lange-Bert. in Lange-Bertalot \& Genkal & & & & $\mathbf{x}$ \\
\hline Amphora copulata (Kütz.) Schoeman \& R.E.M.Archibald & & & & $\mathbf{x}$ \\
\hline Amphora pediculus (Kütz.) Grunow in A.W.F.Schmidt & $\mathbf{x}$ & $\mathbf{x}$ & $\mathbf{x}$ & \\
\hline Amphora sp. & $\mathbf{x}$ & & & \\
\hline Caloneis aerophila W.Bock & $\mathbf{x}$ & $\mathbf{x}$ & $\mathbf{x}$ & \\
\hline Caloneis lancettula (Schulz) Lange-Bert. \& Witkowski in Lange-Bertalot \& Metzeltin & & & $\mathbf{x}$ & \\
\hline Caloneis cf. Iancettula (Schulz) Lange-Bert. \& Witkowski in Lange-Bertalot \& Metzeltin & $\mathbf{x}$ & & & \\
\hline Caloneis fontinalis (Grunow in Van Heurck) A.Cleve & $\mathbf{x}$ & $\mathbf{x}$ & $\mathbf{x}$ & $\mathbf{x}$ \\
\hline Caloneis aff. fontinalis (Grunow in Van Heurck) A.Cleve & $\mathbf{x}$ & $\mathbf{x}$ & & \\
\hline Caloneis leptosoma (Grunow) Krammer in Krammer \& Lange-Bertalot & $\mathbf{x}$ & $\mathrm{x}$ & $\mathbf{x}$ & \\
\hline Caloneis molaris (Grunow) Krammer in Krammer \& Lange-Bertalot & $\mathbf{x}$ & $\mathbf{x}$ & $\mathbf{x}$ & $\mathbf{x}$ \\
\hline Caloneis sp. & $\mathbf{x}$ & $\mathbf{x}$ & $\mathrm{x}$ & $\mathbf{x}$ \\
\hline Caloneis tenuis (W.Gregory) Krammer in Krammer \& Lange-Bertalot & $\mathrm{x}$ & & & \\
\hline Cocconeis lineata Ehrenb. & $\mathbf{x}$ & $\mathbf{x}$ & $\mathbf{x}$ & $\mathbf{x}$ \\
\hline Cocconeis placentula Ehrenb. & & $\mathrm{x}$ & $\mathbf{x}$ & \\
\hline Cocconeis pseudolineata (Geitler) Lange-Bert. in Werum \& Lange-Bertalot & & $\mathrm{x}$ & & \\
\hline Craticula subminuscula (Manguin) C.E.Wetzel \& Ector in Wetzel et al. & & $\mathrm{x}$ & & \\
\hline Crenotia angustior (Grunow) Wojtal & $\mathbf{x}$ & $\mathbf{x}$ & $\mathbf{x}$ & $\mathbf{x}$ \\
\hline Cymbella parva (W.Sm.) Kirchner & & $\mathbf{x}$ & & \\
\hline Diatoma vulgaris Bory & $\mathbf{x}$ & & & $\mathbf{x}$ \\
\hline Diploneis elliptica (Kütz.) Cleve & $\mathbf{x}$ & & $\mathrm{x}$ & \\
\hline Diploneis fontanella Lange-Bert. in Werum \& Lange-Bertalot & & & $\mathbf{x}$ & $\mathbf{x}$ \\
\hline Diploneis aff. fontanella Lange-Bert. in Werum \& Lange-Bertalot & & $\bar{x}$ & $\mathrm{x}$ & \\
\hline Diploneis krammeri Lange-Bert. \& E.Reichardt & $\mathbf{x}$ & $\mathbf{x}$ & $\mathrm{x}$ & $\mathbf{x}$ \\
\hline
\end{tabular}




\begin{tabular}{|c|c|c|c|c|}
\hline Diploneis oculata (Bréb. in Desmazières) Cleve & $\mathbf{x}$ & & $\mathbf{x}$ & $\mathbf{x}$ \\
\hline Diploneis petersenii Hust. & & & $\mathbf{x}$ & \\
\hline Diploneis aff. petersenii Hust. & $\mathbf{x}$ & & & \\
\hline Diploneis separanda Lange-Bert. in Werum \& Lange-Bertalot & & $\mathrm{x}$ & $\mathrm{x}$ & $\mathrm{x}$ \\
\hline Diploneis aff. separanda Lange-Bert. in Werum \& Lange-Bertalot & $\mathrm{x}$ & $\mathbf{x}$ & $\mathrm{x}$ & \\
\hline Diploneis sp. & $\mathbf{x}$ & & & \\
\hline Encyonema lange-bertalotii Krammer & $\mathrm{x}$ & & & \\
\hline Encyonema aff. lange-bertalotii Krammer & & & $\mathrm{x}$ & \\
\hline Encyonema minutum (Hilse in Rabenhorst) D.G.Mann in Round et al. & $\mathbf{x}$ & $\mathbf{x}$ & $\mathrm{x}$ & $\mathbf{x}$ \\
\hline Encyonema perpusillum (A.Cleve) D.G.Mann in Round et al. & & $\mathbf{x}$ & & \\
\hline Encyonema silesiacum (Bleisch in Rabenhorst) D.G.Mann in Round et al. & $\mathrm{x}$ & $\mathrm{x}$ & & \\
\hline Encyonema ventricosum (C.Agardh) Grunow in A.W.F.Schmidt & $\mathrm{x}$ & & $\mathrm{x}$ & \\
\hline Encyonopsis cesatii (Rabenh.) Krammer & & & $\mathbf{x}$ & \\
\hline Epithemia adnata (Kütz.) Bréb. & $\mathrm{x}$ & $\mathbf{x}$ & $\mathrm{x}$ & $\mathrm{x}$ \\
\hline Eunotia boreoalpina Lange-Bert. \& Nörpel-Schempp in Metzeltin \& Lange-Bertalot & & $\mathrm{x}$ & $\mathrm{x}$ & \\
\hline Eunotia exigua (Bréb. ex Kütz.) Rabenh. & $\mathrm{x}$ & & & \\
\hline Eunotia cf. faba Ehrenb. & $\mathbf{x}$ & & & \\
\hline Eunotia minor (Kütz.) Grunow in Van Heurck & $\mathbf{x}$ & $\mathrm{x}$ & & \\
\hline Eunotia cf. minor (Kütz.) Grunow in Van Heurck & & $\mathrm{x}$ & & \\
\hline Eunotia nymanniana Grunow in Van Heurck & $\mathrm{x}$ & & & \\
\hline Eunotia cf. nyamanniana Grunow in Van Heurck & $\mathbf{x}$ & & & \\
\hline Eunotia paratridentula Lange-Bert. \& Kulikovskiy in Kulikovskiy et al. & $\mathbf{x}$ & & & $\mathrm{x}$ \\
\hline Eunotia soleirolii (Kütz.) Rabenh. & $\mathrm{x}$ & & & \\
\hline Eunotia sp. & $\mathrm{x}$ & $\mathrm{x}$ & & $\mathbf{x}$ \\
\hline Fallacia lange-bertalotii (E.Reichardt) E.Reichardt in Rumrich et al. & $\mathrm{x}$ & $\mathrm{x}$ & $\mathrm{x}$ & $\mathrm{x}$ \\
\hline Fallacia pygmaea (Kütz.) Stickle \& D.G.Mann in Round et al. & & $\mathbf{x}$ & $\mathrm{x}$ & \\
\hline Fragilaria sp. & & $\mathbf{x}$ & & \\
\hline Fragilaria vaucheriae (Kütz.) J.B.Petersen & $x$ & $\mathrm{x}$ & & $\mathbf{x}$ \\
\hline Frustulia vulgaris (Thwaites) De Toni & $\mathbf{x}$ & & $\mathrm{x}$ & \\
\hline Geissleria acceptata (Hust.) Lange-Bert. \& Metzeltin & & $\mathrm{x}$ & $\mathbf{x}$ & $\bar{x}$ \\
\hline Geissleria paludosa (Hust.) Lange-Bert. \& Metzeltin & $\mathrm{x}$ & & & $\mathrm{x}$ \\
\hline Gomphonema aff. drutelingense E.Reichardt & & & $\mathrm{x}$ & \\
\hline Gomphonema aff. micropus Kütz. & $\mathbf{x}$ & $\mathrm{x}$ & $\mathrm{x}$ & \\
\hline Gomphonema angustatum (Kütz.) Rabenh. & $\mathbf{x}$ & & & $\mathrm{x}$ \\
\hline Gomphonema calcifugum Lange-Bert. \& E.Reichardt in Lange-Bertalot \& Genkal & $\mathbf{x}$ & $\mathrm{x}$ & & \\
\hline Gomphonema clavatum Ehr. & $\mathrm{x}$ & $\mathbf{x}$ & $\mathbf{x}$ & $\mathrm{x}$ \\
\hline
\end{tabular}




\begin{tabular}{|c|c|c|c|c|}
\hline Gomphonema cymbelliclinum E.Reichardt \& Lange-Bert. in Reichardt & & $\mathbf{x}$ & & $\mathbf{x}$ \\
\hline Gomphonema elegantissimum E.Reichardt \& Lange-Bert. in Hofmann et al. & $x$ & & & \\
\hline Gomphonema cf. elegantissimum E.Reichardt \& Lange-Bert. in Hofmann et al. & & $\mathbf{x}$ & & \\
\hline Gomphonema exilissimum (Grun.) Lange-Bert. \& E.Reichardt in Lange-Bertalot \& Metzeltin & & & $\mathrm{x}$ & $\mathbf{x}$ \\
\hline Gomphonema hebridense W.Gregory & & & $\mathrm{x}$ & \\
\hline Gomphonema lagenula Kütz. & & $\mathbf{x}$ & $\mathbf{x}$ & \\
\hline Gomphonema minutum (C.Agardh.) C.Agardh & $\mathbf{x}$ & & & \\
\hline Gomphonema parvulum Kütz. & $\mathbf{x}$ & $\mathrm{x}$ & $\mathrm{x}$ & $\mathbf{x}$ \\
\hline Gomphonema aff. parvulum Kütz. & & & & $\mathrm{x}$ \\
\hline Gomphonema productum (Grunow) Lange-Bert. \& E.Reichardt in Lange-Bertalot & & $\mathbf{x}$ & & \\
\hline Gomphonema pseudobohemicum Lange-Bert. \& E.Reichardt in Lange-Bertalot \& Metzeltin & $\mathbf{x}$ & & & \\
\hline Gomphonema sarcophagus W.Gregory & & & & $\mathbf{x}$ \\
\hline Gomphonema sp. & $\mathbf{x}$ & $\mathbf{x}$ & $\mathbf{x}$ & \\
\hline Gomphonema utae Lange-Bert. \& E.Reichardt in Reichardt & & & $\mathrm{x}$ & \\
\hline Halamphora coffeaeformis (C.Agardh) Levkov & $\mathrm{x}$ & & & \\
\hline Halamphora normanii (Rabenh.) Levkov & $\mathbf{x}$ & $\mathbf{x}$ & $\mathbf{x}$ & $\mathbf{x}$ \\
\hline Halamphora sp. & $\mathbf{x}$ & $\mathbf{x}$ & $\mathbf{x}$ & \\
\hline Halamphora veneta (Kütz.) Levkov & $\mathbf{x}$ & & & $\mathbf{x}$ \\
\hline Hannaea arcus (Ehr.) R.M.Patrick in Patrick \& Reimer & & $\mathbf{x}$ & & \\
\hline Hantzschia amphioxys (Ehr.) Grunow in Cleve \& Grunow & & $\mathrm{x}$ & & \\
\hline Hantzschia calcifuga E.Reichardt \& Lange-Bert. in Werum \& Lange-Bertalot & & $\mathbf{x}$ & $\mathrm{x}$ & \\
\hline Hantzschia aff. calcifuga E. Reichardt \& Lange-Bert. in Werum \& Lange-Bertalot & & & $\mathrm{x}$ & \\
\hline Hantzschia abundans Lange-Bert. & $\mathbf{x}$ & $\mathbf{x}$ & & \\
\hline Hippodonta capitata (Ehr.) Lange-Bert., Metzeltin \& Witkowski & $x$ & $\mathrm{x}$ & $\mathrm{x}$ & \\
\hline $\begin{array}{l}\text { Humidophila contenta (Grunow) R.L.Lowe, Kociolek, J.R.Johansen, Van de Vijver, Lange-Bert. \& } \\
\text { Kopalová }\end{array}$ & $\mathbf{x}$ & $\mathbf{x}$ & $\mathbf{x}$ & $\mathbf{x}$ \\
\hline Humidophila gallica (W.Sm.) R.L.Lowe, Kociolek, Q.You, Q.Wang \& Stepanek & $\mathbf{x}$ & $\mathrm{x}$ & $\mathrm{x}$ & $\mathbf{x}$ \\
\hline $\begin{array}{l}\text { Humidophila perpusilla (Grunow) R.L.Lowe, Kociolek, J.R.Johansen,Van de Vijver, Lange-Bert. \& } \\
\text { Kopalová }\end{array}$ & $\mathbf{x}$ & $\mathbf{x}$ & $\mathrm{x}$ & $\mathbf{x}$ \\
\hline Humidophila sp. & & $\mathbf{x}$ & & \\
\hline Kolbesia gessneri (Hust.) Aboal & & $\mathrm{x}$ & & \\
\hline Lindavia radiosa (Grunow) De Toni \& Forti & $\mathbf{x}$ & & $\mathbf{x}$ & \\
\hline Luticola acidoclinata Lange-Bert. in Lange-Bertalot \& Metzeltin & & $\mathbf{x}$ & $\mathrm{x}$ & $\bar{x}$ \\
\hline Luticola aff. acidoclinata Lange-Bert. in Lange-Bertalot \& Metzeltin & & & & $\mathbf{x}$ \\
\hline Luticola frequentissima Levkov, Metzeltin \& A.Pavlov & & $\mathrm{x}$ & & \\
\hline Luticola mutica (Kütz. ) D.G.Mann in Round et al. & $\mathrm{x}$ & $\mathbf{x}$ & $\mathrm{x}$ & $\mathbf{x}$ \\
\hline Luticola aff. mutica (Kütz.) D.G.Mann in Round et al. & $x$ & & $\mathrm{x}$ & \\
\hline Luticola nivalis (Ehrenb.) D.G.Mann in Round et al. & & $x$ & & \\
\hline
\end{tabular}




\begin{tabular}{|c|c|c|c|c|}
\hline Luticola pitranenis Levkov, Metzeltin \& A.Pavlov in Levkov et al. & & & $\mathbf{x}$ & \\
\hline Mayamaea permitis (Hust.) Bruder \& Medlin & & & $\mathbf{x}$ & \\
\hline Meridion circulare (Grev.) C.Agardh & $\mathbf{x}$ & $\mathbf{x}$ & & $\bar{x}$ \\
\hline Meridion constrictum Ralfs & $\mathbf{x}$ & & $\bar{x}$ & \\
\hline Navicula antonii Lange-Bert. in Rumrich et al. & & $\mathbf{x}$ & & \\
\hline Navicula catalanogermanica Lange-Bert. \& G.Hofm. in Lange-Bertalot & & $\mathbf{x}$ & & \\
\hline Navicula cincta (Ehr.) Ralfs in Pritchard & $\mathbf{x}$ & $\mathrm{x}$ & & $\mathrm{x}$ \\
\hline Navicula aff. cincta (Ehr.) Ralfs in Pritchard & $\mathbf{x}$ & & & \\
\hline Navicula cryptotenella Lange-Bert. in Krammer \& Lange-Bertalot & $x$ & $\mathbf{x}$ & $x$ & \\
\hline Navicula gregaria Donkin & $\mathbf{x}$ & $\mathbf{x}$ & & \\
\hline Navicula aff. hintzii Lange-Bert. & & & $\mathbf{x}$ & \\
\hline Navicula lanceolata Ehrenb. & $\mathbf{x}$ & $\mathbf{x}$ & $\mathrm{x}$ & $\bar{x}$ \\
\hline Navicula moenofranconica Lange-Bert. & $\mathbf{x}$ & & & \\
\hline Navicula aff. moenofranconica Lange-Bert & & $\mathrm{x}$ & $\mathrm{x}$ & \\
\hline Navicula salinarum Grunow in Cleve \& Grunow & & $\mathbf{x}$ & $\mathrm{x}$ & $\mathrm{x}$ \\
\hline Navicula sanctamargaritae Beauger in Beauger et al. & $\mathrm{x}$ & $\mathrm{x}$ & $\mathbf{x}$ & $\mathrm{x}$ \\
\hline Navicula seibigiana Lange-Bert. & & & & $\bar{x}$ \\
\hline Navicula sp. & $\mathrm{x}$ & $\mathbf{x}$ & $\mathrm{x}$ & \\
\hline Navicula tripunctata (O.F.Müll.) Bory & & $\mathbf{x}$ & $\mathbf{x}$ & \\
\hline Navicula veneta Kütz. & $\mathrm{x}$ & $\mathrm{x}$ & & $\bar{x}$ \\
\hline Neidium sp. & & & & $\mathrm{x}$ \\
\hline Nitzschia amphibia Grunow & $\mathbf{x}$ & $\mathbf{x}$ & & $\mathrm{x}$ \\
\hline Nitzschia aff. amphibia Grunow & & $\mathrm{x}$ & $\mathrm{x}$ & \\
\hline Nitzschia austriaca Hust. & & $x$ & $x$ & \\
\hline Nitzschia communis Rabenh. & & & & $\bar{x}$ \\
\hline Nitzschia commutata Grunow in Cleve \& Grunow & & & & $\bar{x}$ \\
\hline Nitzschia cf. commutata Grunow in Cleve \& Grunow & & $\mathbf{x}$ & & \\
\hline Nitzschia dissipata (Kütz.) Rabenh. & $x$ & $\mathrm{x}$ & & $\mathrm{x}$ \\
\hline Nitzschia fonticola (Grunow) Grunow in Van Heurck & $\mathbf{x}$ & $\mathrm{x}$ & & \\
\hline Nitzschia gracilis Hantzsch & & & & $\bar{x}$ \\
\hline Nitzschia hantzschiana Rabenh. & $\mathbf{x}$ & & & $x$ \\
\hline Nitzschia aff. hantzschiana Rabenh. & $\mathrm{x}$ & & & \\
\hline Nitzschia cf. liebetruthii Rabenh. & $x$ & & $\mathrm{x}$ & \\
\hline Nitzschia linearis W.Sm. & $\mathrm{x}$ & $\mathbf{x}$ & $\mathrm{x}$ & $\mathrm{x}$ \\
\hline Nitzschia palea (Kütz.) W.Sm. & & $\mathrm{x}$ & $\mathrm{x}$ & \\
\hline Nitzschia cf. perspicua Cholnoky & & $x$ & & $\bar{x}$ \\
\hline
\end{tabular}




\begin{tabular}{|c|c|c|c|c|}
\hline Nitzschia aff. recta Hantzsch ex Rabenhorst & & & $\mathrm{x}$ & $\bar{x}$ \\
\hline Nitzschia solgensis A.Cleve & $\mathrm{x}$ & & & \\
\hline Nitzschia soratensis E.Morales \& M.L.Vis & $\bar{x}$ & $\mathrm{x}$ & & $\bar{x}$ \\
\hline Nitzschia supralitorea Lange-Bert. & & $\mathbf{x}$ & $\mathbf{x}$ & $\mathbf{x}$ \\
\hline Nitzschia sp. & & $\mathrm{x}$ & & \\
\hline Nupela lapidosa (Krasske) Lange-Bert. & $\mathbf{x}$ & & & \\
\hline Orthoseira roeseana (Rabenh.) Pfitzer & $\mathbf{x}$ & $\mathbf{x}$ & $\mathbf{x}$ & $\mathbf{x}$ \\
\hline Parlibellus protractus (Grunow) Witkowski, Lange-Bert. \& Metzeltin & & $\mathbf{x}$ & & \\
\hline Pinnularia borealis Ehrenb. & $\mathbf{x}$ & $\mathbf{x}$ & & $\mathbf{x}$ \\
\hline Pinnularia brebissonii (Kütz.) Rabenh. & & $\mathbf{x}$ & $\mathrm{x}$ & \\
\hline Pinnularia aff. frequentis Krammer & & $\mathbf{x}$ & & \\
\hline Pinnularia aff. kuetzingii Krammer & $\mathbf{x}$ & $\mathbf{x}$ & $\mathrm{x}$ & $\mathbf{x}$ \\
\hline Pinnularia obscura Krasske & $\mathbf{x}$ & $\mathbf{x}$ & & \\
\hline Pinnularia aff. obscura Krasske & & $\mathbf{x}$ & & \\
\hline Pinnularia peracuminata Krammer & $\mathbf{x}$ & $\mathbf{x}$ & $\mathrm{x}$ & $\bar{x}$ \\
\hline Pinnularia aff. peracuminata Krammer & & & $\mathrm{x}$ & \\
\hline Pinnularia aff. perirrorata Krammer & & & $\mathrm{x}$ & \\
\hline Pinnularia rupestris Hantzsch in Rabenhorst & & & $\mathrm{x}$ & \\
\hline Pinnularia aff. rupestris Hantzsch in Rabenhorst & & $\mathbf{x}$ & & \\
\hline Pinnularia schoenfelderi Krammer & $\mathrm{x}$ & & & \\
\hline Pinnularia sinistra Krammer & $\mathbf{x}$ & & & $\mathbf{x}$ \\
\hline Pinnularia sp. & $\mathrm{x}$ & & $\mathrm{x}$ & \\
\hline Pinnularia sp. 2 & $\mathbf{x}$ & & & \\
\hline Pinnularia subrupestris Krammer & $\mathrm{x}$ & & $\mathrm{x}$ & $\mathbf{x}$ \\
\hline Pinnularia aff. subrupestris Krammer & $\mathbf{x}$ & & & \\
\hline Pinnularia aff. subsilvatica Krammer \& Lange-Bert. in Krammer & & $\mathrm{x}$ & & \\
\hline Pinnularia viridiformis Krammer & $\mathrm{x}$ & $\mathrm{x}$ & & $\mathrm{x}$ \\
\hline Placoneis paraelginensis Lange-Bert. in Rumrich et al. & $\mathbf{x}$ & & $\mathrm{x}$ & \\
\hline Placoneis aff. paraelginensis Lange-Bert. in Rumrich et al. & & 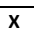 & $\mathrm{x}$ & \\
\hline Planothidium frequentissimum (Lange-Bert.) Lange-Bert. & $\mathbf{x}$ & $\mathbf{x}$ & $\mathrm{x}$ & $\bar{x}$ \\
\hline Planothidium lanceolatum (Bréb. ex Kützing) Lange-Bert. & $\mathrm{x}$ & $\mathrm{x}$ & $\mathrm{x}$ & $\mathrm{x}$ \\
\hline Psammothidium subatomoides (Hust.) Bukht. \& Round & & $\mathbf{x}$ & $x$ & \\
\hline Pseudostaurosira sp. & $\mathrm{x}$ & $\mathrm{x}$ & & \\
\hline Reimeria sinuata (W.Gregory) Kociolek \& Stoermer & $\mathbf{x}$ & $\mathbf{x}$ & $\mathrm{x}$ & $\bar{x}$ \\
\hline Reimeria sp. & & $\mathbf{x}$ & & $\mathbf{x}$ \\
\hline Rhoicosphenia abbreviata (C.Agardh) Lange-Bert. & $\mathrm{x}$ & $\mathbf{x}$ & $x$ & $\bar{x}$ \\
\hline Rhopalodia acuminata Krammer in Lange-Bertalot \& Krammer & $\mathbf{x}$ & $\mathbf{x}$ & $\mathbf{x}$ & $\mathbf{x}$ \\
\hline
\end{tabular}




\begin{tabular}{|c|c|c|c|c|}
\hline Rhopalodia brebissonii Krammer in Lange-Bertalot \& Krammer & & $\mathbf{x}$ & $\mathrm{x}$ & $\mathbf{x}$ \\
\hline Rhopalodia gibba (Ehrenb.) O.Müll. & & & & $\mathbf{x}$ \\
\hline Rhopalodia gibberula (Ehrenb.) O.Müll. & & $\mathbf{x}$ & & \\
\hline Rhopalodia operculata (C.Agardh) Håk. & & & & $\mathbf{x}$ \\
\hline Rhopalodia sp. & & & & $\mathbf{x}$ \\
\hline Sellaphora atomoides C.E.Wetzel \& Van de Vijver in Wetzel et al. & $\mathbf{x}$ & $\mathbf{x}$ & $\mathrm{x}$ & $\mathbf{x}$ \\
\hline Sellaphora labernardierei Beauger, C.E.Wetzel \& Ector in Beauger et al. & $\mathbf{x}$ & $\mathbf{x}$ & $\mathbf{x}$ & $\mathbf{x}$ \\
\hline Sellaphora nigri (De Not.) C.E.Wetzel \& Ector in Wetzel et al. & & & $\mathbf{x}$ & $\mathbf{x}$ \\
\hline Sellaphora pseudopupula (Krasske) Lange-Bert. in Lange-Bertalot et al. & $\mathbf{x}$ & $\mathrm{x}$ & & \\
\hline Sellaphora aff. pseudopupula (Krasske) Lange-Bert. in Lange-Bertalot et al. & $\mathbf{x}$ & & & \\
\hline Sellaphora cf. pseudopupula (Krasske) Lange-Bert. in Lange-Bertalot et al. & $\mathbf{x}$ & & & $\mathbf{x}$ \\
\hline Sellaphora pupula (Kütz.) Mereschk. & & $\mathrm{x}$ & $\mathbf{x}$ & $\mathbf{x}$ \\
\hline Sellaphora saugerresii (Desm.) C.E.Wetzel \& D.G.Mann in Wetzel et al. & & $\mathrm{x}$ & $\mathbf{x}$ & $\mathbf{x}$ \\
\hline Sellaphora seminulum (Grunow) D.G.Mann & & $\mathbf{x}$ & $\mathbf{x}$ & \\
\hline Stauroneis cf. muriella J.W.G.Lund & & $\mathrm{x}$ & & \\
\hline Stauroneis leguminopsis Lange-Bert. \& Krammer in Lange-Bertalot \& Genkal & & $\mathbf{x}$ & $\mathbf{x}$ & \\
\hline Stauroneis parathermicola Lange-Bert. in Hofman et al. & & $\mathbf{x}$ & $\mathbf{x}$ & $\mathbf{x}$ \\
\hline Staurosira pinnata Ehrenb. & & $\mathbf{x}$ & & \\
\hline Surirella aff. terricola Lange-Bert. \& Alles in Lange-Bertalot \& Metzeltin & $\mathbf{x}$ & & & \\
\hline Surirella brebissonii Krammer \& Lange-Bert. & & & & $\bar{x}$ \\
\hline Surirella linearis W.Sm. & & $\mathbf{x}$ & & \\
\hline Surirella sp. & $\mathbf{x}$ & $\mathbf{x}$ & & \\
\hline Tryblionella debilis Arnott ex O'Meara & & & $\mathbf{x}$ & $\mathbf{x}$ \\
\hline
\end{tabular}


